\title{
Cerebrospinal fluid biomarkers in human genetic transmissible spongiform encephalopathies
}

\author{
Anna Ladogana · Pascual Sanchez-Juan · Eva Mitrová · Alison Green · Natividad Cuadrado-Corrales · \\ Raquel Sánchez-Valle · Silvia Koscova · Adriano Aguzzi · Theodoros Sklaviadis · Jerzy Kulczycki · \\ Joanna Gawinecka · Albert Saiz · Miguel Calero · Cornelia M. van Duijn · Maurizio Pocchiari · \\ Richard Knight $\cdot$ Inga Zerr
}

Received: 16 December 2008/Revised: 8 April 2009/Accepted: 27 April 2009/Published online: 15 May 2009

(C) Springer-Verlag 2009

\begin{abstract}
The 14-3-3 protein test has been shown to support the clinical diagnosis of sporadic Creutzfeldt-Jakob disease (CJD) when associated with an adequate clinical context, and a high differential potential for the diagnosis of sporadic CJD has been attributed to other cerebrospinal fluid (CSF) proteins such as tau protein, S100b and neuron specific enolase (NSE). So far there has been only limited information available about biochemical markers
\end{abstract}

\author{
A. Ladogana $\cdot$ M. Pocchiari \\ Department of Cellular Biology and Neurosciences, Instituto \\ Superiore di Sanita, Viale Regina Elena 299, 00161 Rome, Italy \\ e-mail: Ladogana@iss.it \\ M. Pocchiari \\ e-mail: Maurizio.pocchiari@iss.it \\ P. Sanchez-Juan \\ Centro de Investigacion Biomedica en Red sobre Enferemedades \\ neurodegenerativas (CIBERNED) and Institute for Formation \\ and Research of the Fundacion "Marques de Valdecilla" \\ (IFIMAV), Santander, Spain \\ e-mail: ifimav.uapoyo@fmdv.org \\ E. Mitrová $\cdot$ S. Koscova \\ National Reference Centre for Prion Diseases, \\ Research Base of Slovak Medical University, \\ Limbová 14, 833-03 Bratislava, Slovakia \\ e-mail: eva.mitrova@szu.sk \\ S. Koscova \\ e-mail: silvia.koscova@szu.sk \\ A. Green · R. Knight \\ National CJD Surveillance Unit, The University of Edinburgh, \\ EH4-2XU Edinburgh, UK \\ e-mail: Alison.Green@ed.ac.uk \\ N. Cuadrado-Corrales $\cdot$ M. Calero \\ Instituto de Salud Carlos III, Centro Nacional de Microbiologia, \\ Ctra. Majadahonda, 28220 Madrid, Spain \\ e-mail: ncuadrado@isciii.es
}

in genetic transmissible spongiform encephalopathies (gTSE), although they represent 10-15\% of human TSEs. In this study, we analyzed CSF of 174 patients with gTSEs for 14-3-3 $(n=166)$, tau protein $(n=78)$, S100b $(n=46)$ and NSE $(n=50)$. Levels of brain-derived proteins in CSF varied in different forms of gTSE. Biomarkers were found positive in the majority of gCJD (81\%) and insert gTSE (69\%), while they were negative in most cases

M. Calero

e-mail: mcalero@isciii.es

R. Sánchez-Valle · A. Saiz

Department of Neurology,

Hospital Clinic Provincial de Barcelona,

Villarroel 170, 08036 Barcelona, Spain

e-mail: 31799rsd@comb.es

A. Saiz

e-mail: asaiz@clinic.ub.es

\section{A. Aguzzi}

National Reference Center for Human Prion Diseases (NRPE), Institute of Neuropathology, Schmelzbergstr.12,

8091 Zurich, Switzerland

e-mail: adriano.aguzzi@usz.ch

T. Sklaviadis

Laboratory of Pharmacology,

Department of Pharmaceutical Sciences,

School of Health Sciences,

Aristotle University of Thessaloniki,

54124 Thessaloníki, Greece

e-mail: sklaviad@pharm.auth.gr

J. Kulczycki

I-st Neurological Department,

Institute of Psychiatry and Neurology, Sobieskiego 9,

02-957 Warsaw, Poland

e-mail: jkulczycki@data.pl 
of fatal familial insomnia (13\%) and Gerstmann-SträusslerScheinker syndrome (10\%). Disease duration and codon 129 genotype influence the findings in a different way than in sporadic CJD.

Keywords Creutzfeldt-Jakob disease - CSF proteins . 14-3-3 protein $\cdot$ Tau

\section{Introduction}

The analysis of cerebrospinal fluid (CSF) in patients with suspected Creutzfeldt-Jakob disease (CJD) is an important investigation for the differential diagnosis of CJD from among other forms of rapid progressive dementia. The 14-3-3 protein levels are often increased in the CSF of sporadic CJD patients, and this test has therefore been included in the diagnostic criteria for sporadic CJD when associated with an appropriate clinical profile [6, 31]. Increased levels of other brain-derived proteins, such as tau protein, S100b or neuron-specific enolase (NSE) have also been reported, but information on these markers is limited [20, 27]. However, in most gTSE, studies of CSF proteins report 14-3-3 test results only in gCJD with E200K and V210I point mutations. Levels of brain-derived proteins are low in Gerstmann-Sträussler-Scheinker syndrome (GSS) and almost all fatal familial insomnia (FFI) patients reported to date are negative for 14-3-3 [11, 15, 20, 30].

A very few data are available on the levels of the other marker proteins in the CSF of patients with gTSEs, and no analyses on factors influencing the percentage of elevated levels have been done. In this paper, we perform such an analysis on brain-derived proteins in patients having gTSE with various mutations.

\section{Methods}

Patients and database

The study was performed in the framework of the ECsupported multinational study on biomarkers in prion diseases (CJD markers) [20].

\footnotetext{
J. Gawinecka $\cdot$ I. Zerr $(\bowtie)$

National Reference Center for Transmissible Spongiform

Encephalopathies, Department of Neurology,

Georg-August-University Göttingen, Robert-Koch-Str. 40,

37075 Göttingen, Germany

e-mail: epicjd@med.uni-goettingen.de

C. M. van Duijn

Department of Epidemiology and Biostatistics,

Erasmus University Medical Center Rotterdam, PO Box 1738,

3000 DR Rotterdam, The Netherlands

e-mail: c.vanduijn@erasmusmc.nl
}

A database was set up which included detailed data on 180 patients with genetic TSE, 61 (34\%) gTSE patients from Germany, 58 (32\%) from Italy, $36(20 \%)$ from Spain, $13(7 \%)$ from the UK, $10(5 \%)$ from Slovakia and $2(1 \%)$ from Switzerland.

The diagnoses of gTSE were carried out according to recent surveillance criteria after $P R N P$ analysis [11, 12]. For the estimation of the disease stage when the LP was performed we divided the individual disease duration in thirds and calculated the time of lumbar puncture according to the first third of the total duration of the disease (early stage), the second (middle) or the third (advanced stage) of the disease.

\section{CSF tests}

14-3-3 and other tests were performed according to previously described methods [20].

\section{Statistical analyses}

Differences in CSF levels of tau, S100b and NSE proteins across the four genetic groups of gTSE were separately assessed by the Kruskal-Wallis test, followed, when statistically significant, by the Mann-Whitney test. Since different techniques were employed for the determination of $\mathrm{S} 100 \mathrm{~b}$ and $\mathrm{NSE}$, we included in the quantitative assessment levels only the results of the most frequently used kits (Byk Sangtec for S100b and -Hofman LaRoche for NSE).

We then calculated the percentage of positive results out of the total for each CSF marker in the four genetic groups. All samples were included in the analysis, since a positive result was calculated according to the cut-off of the different techniques. The $\chi^{2}$ test was used to assess differences between categorical variables.

A multiple logistic regression model was used to assess the effect of a set of clinically relevant variables on the percentage of elevated levels of the different biomarkers in gTSE patients. These were: type of disease causing mutation, disease duration (in months), age at onset (in years), disease stage when the lumbar puncture was performed (during the first, second or third period of disease duration), and PRNP codon 129 genotype. Country of patient and gender were entered as covariates. Age at onset was categorized in four clinically meaningful groups, with younger than 40 years as the reference group. Disease duration was categorized in two groups (short and long duration), according to the median survival time. Due to the small numbers of patients, some of the statistical analyses were restricted to gCJD groups or to the 14-3-3 test. 


\section{Results}

General description

Demographic and clinical information on gTSE cases is given in Table 1. A definite neuropathological diagnosis was available in $52 \%$ of the cases, ranging from more than $87 \%$ of FFI to $22 \%$ of GSS patients, while in $47 \%$ of gCJD autopsy was not performed. Data on the polymorphic codon 129 of PRNP were available in $86 \%$ of all cases. For some patients the only available information was about PRNP with no information on codon 129 genotype. The majority of gTSE patients were either homozygous for methionine (MM, 58\%) or heterozygous (MV, 36\%), only a few were homozygous for valine $(6 \%)$. In a few cases, where the $\operatorname{PrP}^{\mathrm{Sc}}$ typing was available, it was invariable $\operatorname{PrP}^{\mathrm{Sc}}$ type I pattern.

Quantitative levels of brain-derived proteins

The CSF concentrations of tau protein ranged from 70.0 to $35,440.0 \mathrm{pg} / \mathrm{ml}$ (median 6,255.5 pg/ml) in the gCJD group, from 75.0 to $20,370.0 \mathrm{pg} / \mathrm{ml}$ (median 2,354.0 pg/ml) in the insert gTSE group, from 296.0 to $1,698.0 \mathrm{pg} / \mathrm{ml}$ (median $675.0 \mathrm{pg} / \mathrm{ml}$ ) in the GSS group, and from 97.0 to $4,126.0 \mathrm{pg} / \mathrm{ml}$ (median $464.5 \mathrm{pg} / \mathrm{ml}$ ) in the FFI group (Fig. 1a). CSF levels of tau protein significantly differ in the four groups of gTSEs ( $p<0.001$, Kruskal-Wallis test), but did not vary within the gCJD group of patients $(p=0.13)$.

The median CSF concentrations of S100b protein were above the cut-off level in all groups but one (FFI), ranging from 1.0 to $16.0 \mathrm{ng} / \mathrm{ml}$ in gCJD (median $9.0 \mathrm{ng} / \mathrm{ml}$ ), from 3.0 to $17.0 \mathrm{ng} / \mathrm{ml}$ in insert gTSE (median $11.0 \mathrm{ng} / \mathrm{ml}$ ), and from 1.0 to $6.0 \mathrm{ng} / \mathrm{ml}$ in FFI (median $3.0 \mathrm{ng} / \mathrm{ml}$ ), Fig. $1 \mathrm{~b}$. The only GSS patient tested for S100b protein had a CSF concentration of $23.0 \mathrm{ng} / \mathrm{ml}$. Statistical analysis showed a significant difference among the three groups ( $p=0.002$, Kruskal-Wallis test).

The CSF concentrations of NSE protein ranged from 15.0 to $140.0 \mathrm{ng} / \mathrm{ml}$ (median $38.5 \mathrm{ng} / \mathrm{ml}$ ) in only $10 \mathrm{gCJD}$ patients where it was tested, from 10.0 to $190.0 \mathrm{ng} / \mathrm{ml}$ (median $17.0 \mathrm{ng} / \mathrm{ml})$ in insert gTSE $(n=5)$, and from 9.0 to $16.0 \mathrm{ng} / \mathrm{ml}$ (median $12.5 \mathrm{ng} / \mathrm{ml}$ ) in FFI $(n=2)$. The GSS patient tested for NSE protein had a CSF concentration of $13.0 \mathrm{ng} / \mathrm{ml}$. Difference in CSF levels of NSE protein within the four groups of gTSE patients did not reach significance ( $p=0.08$, Kruskal-Wallis test) (Fig. 1c).

Abnormal cerebrospinal fluid findings in gTSEs

\section{4-3-3}

There was a statistically significant difference in the rate of elevated 14-3-3 levels among the four groups of gTSEs, $(p<0.001)$, see Table 2. A 14-3-3 positive test was present in the majority of gCJD patients, irrespective of the mutation they carried (R208H, V203I, E211Q, T188K, and $\mathrm{R} 148 \mathrm{H})$. Thus, no significant difference in percentage of abnormal tests for 14-3-3 was found between E200K (81\%) andV210I $(85 \%)$ or versus other forms of $\mathrm{gCJD}(72 \%)$. Insert gTSE patients had also a high proportion of positive tests $(69 \%)$, while the $14-3-3$ test was positive in only $10 \%$ of GSS and in $13 \%$ of FFI cases.

\section{Tau}

A high rate of tau levels was found in gCJD and insert gTSE groups, while in GSS only $40 \%$ of cases had tau levels above the cut-off level of $1,300 \mathrm{pg}$. Only a single FFI patient had abnormal tau levels in CSF (Table 2). The levels of tau protein in the CSF were statistically different in the four groups $(p<0.001)$.

Table 1 Summary of clinical features of patients in the study

\begin{tabular}{|c|c|c|c|c|c|c|c|c|}
\hline \multirow{2}{*}{$\begin{array}{l}\text { Forms of } \\
\text { gTSE }\end{array}$} & \multirow{2}{*}{$\begin{array}{l}\text { Number of cases } \\
\text { total (female } \\
\text { gender) }\end{array}$} & \multirow{2}{*}{$\begin{array}{l}\text { Percentage of } \\
\text { neuropatho-logically } \\
\text { confirmed cases }(n)\end{array}$} & \multirow{2}{*}{$\begin{array}{l}\text { Age at onset, } \\
\text { years, median } \\
\text { (range) }\end{array}$} & \multirow{2}{*}{$\begin{array}{l}\text { Clinical duration, } \\
\text { months, median } \\
\text { (range) }\end{array}$} & \multicolumn{3}{|c|}{ Codon 129 polymorphism } & \multirow[t]{2}{*}{ PrP type I } \\
\hline & & & & & $\mathrm{MM} \%(n)$ & $\operatorname{MV} \%(n)$ & $\mathrm{VV} \%(n)$ & \\
\hline gCJD & $124(68)$ & & & & & & & \\
\hline E200K & $64(37)$ & $54.7(35)$ & $59(29-86)$ & $6(0.43-34)$ & $63.5(33)$ & $36.5(19)$ & $0.0(0)$ & $4 / 4$ \\
\hline V210I & $40(19)$ & $47.5(19)$ & $56.5(43-87)$ & $4(1-31)$ & $67.5(27)$ & $32.5(13)$ & $0.0(0)$ & $5 / 5$ \\
\hline Other & $20(12)$ & $28.6(6)$ & $65(32-77)$ & $6.5(2-12)$ & $37.5(6)$ & $31.3(5)$ & $31.3(5)$ & $3 / 3$ \\
\hline FFI & $23(5)$ & $87(20)$ & $56(24-83)$ & $12.5(1-97)$ & $60.9(14)$ & $39.1(9)$ & $0.0(0)$ & \\
\hline GSS & $10(4)$ & $22(2)$ & $50(25-70)$ & $80.5(54-87)$ & $30.0(3)$ & $60.0(6)$ & $10.0(1)$ & \\
\hline A117V & 1 & & & & & & & \\
\hline P102L & 8 & & & & & & & \\
\hline P105L & 1 & & & & & & & \\
\hline Insert gTSE & $17(11)$ & $52.9(9)$ & $63(36-77)$ & $11(3-19)$ & 46.7 (7) & $33.3(5)$ & $20.0(3)$ & $1 / 1$ \\
\hline
\end{tabular}



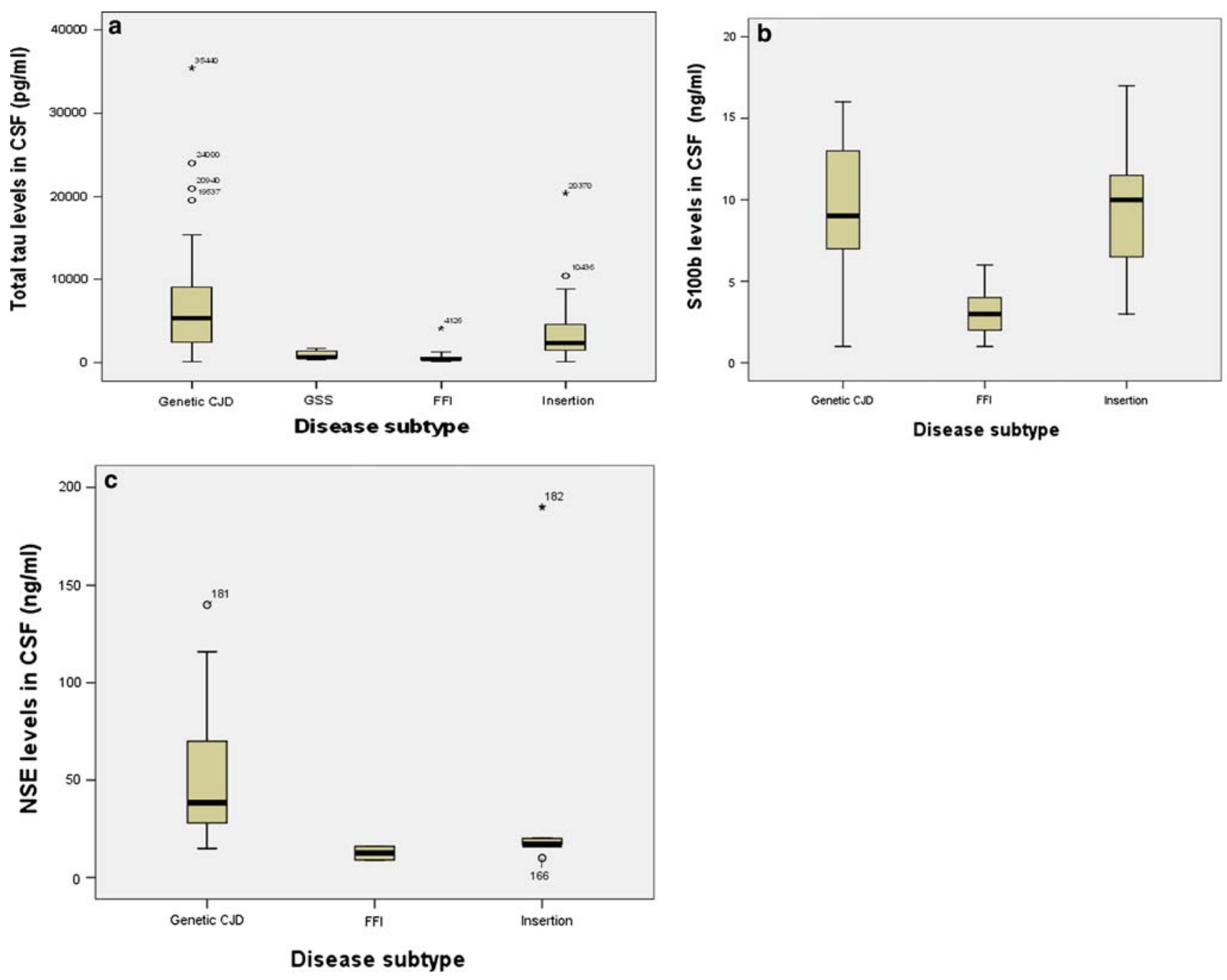

Fig. 1 a Box plots of CSF markers: total CSF tau protein levels in $\operatorname{gCJD}(n=52)$, GSS $(n=6)$, FFI $(n=18)$, and insert gTSE subjects $(n=17)$. b Box plots of CSF S100b protein levels in $\mathrm{gCJD}(n=15)$, FFI $(n=13)$, and insert gTSE subjects $(n=9)$. $\mathbf{c}$ Box plots of CSF levels of NSE in $\operatorname{gCJD}, \mathrm{FF} 1(n=13)$, and insert gTSE subjects

$(n=9)$. The line in the middle of the boxes represents the median. The box extends from the 25 th to the 75 th percentile, bars indicate the range of data distribution. The lines emerging from the box represent the upper and lower adjacent values. Asterisks represent values more extreme than the adjacent values referred to as outliers

\section{S100b}

A similar distribution was observed for $\mathrm{S} 100 \mathrm{~b}$ values. Elevated S100b levels were found in $87 \%$ of gCJD and $77.8 \%$ of insert gTSE patients. These values were lower in GSS and FFI patients. The differences in the gTSE groups were statistically significant, $(p=0.002)$.

NSE

Only $64.3 \%$ of gCJD patients and $50 \%$ of insert gTSE patients had NSE values above the cut-off level, while NSE values were normal in GSS and FFI patients.

\section{Effect of octapeptide repeats}

The number of octapeptide repeats was inversely correlated with the values of tau (Spearman $\rho-0.51(p=0.036)$ ); patients with high number of repeats $(5 \times 24)$ had low tau levels. A similar trend was found for the 14-3-3 test; patients with high number of repeats had low percentage of abnormal tests : $1 \times 24(1 / 1) ; 3 \times 24(1 / 1) ; 4 \times 24(5 / 5)$; $5 \times 24(5 / 10)$ Fisher's $p$ value $=0.22$.

Effects of patient characteristics on abnormal findings

The effect of clinical characteristics on percentage of abnormal findings in gCJD patients was the age at disease 
Table 2 Sensitivity (positive/ total) of CSF investigations by forms of gTSE

\begin{tabular}{|c|c|c|c|c|}
\hline & $14-3-3$ & Tau & $\mathrm{S} 100 \mathrm{~b}$ & NSE \\
\hline gCJD & $83.0(97 / 117)$ & $86.4(38 / 44)$ & $87.0(20 / 23)$ & $64.3(18 / 28)$ \\
\hline E200K & $80.3(49 / 61)$ & $75.0(15 / 20)$ & $92.9(13 / 14)$ & $45.4(5 / 11)$ \\
\hline V210I & $85.0(34 / 40)$ & $100(13 / 13)$ & $100(4 / 4)$ & $75.0(6 / 8)$ \\
\hline D178N-Val & $33.3(1 / 3)$ & $100(1 / 1)$ & $0.0(0 / 1)$ & $100.0(1 / 1)$ \\
\hline R208H & $100(3 / 3)$ & $100(2 / 2)$ & & $100.0(1 / 1)$ \\
\hline V203I & $100(2 / 2)$ & & & \\
\hline E211Q & $100(2 / 2)$ & $100(2 / 2)$ & $100(1 / 1)$ & $100(1 / 1)$ \\
\hline E196K & $100(2 / 2)$ & $100(3 / 3)$ & $100(2 / 2)$ & $100(3 / 3)$ \\
\hline T188K & $100(2 / 2)$ & $100(1 / 1)$ & & $50.0(1 / 2)$ \\
\hline G114V & $0.0(0 / 1)$ & $0.0(0 / 1)$ & $0.0(0 / 1)$ & $0.0(0 / 1)$ \\
\hline R148H & $100(1 / 1)$ & $100(1 / 1)$ & & \\
\hline Insert gTSE & $68.8(11 / 16)$ & $80.0(12 / 15)$ & $77.8(7 / 9)$ & $50.0(4 / 8)$ \\
\hline GSS & $10.0(1 / 10)$ & $40.0(2 / 5)$ & $50.0(2 / 4)$ & $0.0(0 / 2)$ \\
\hline A117V & $0.0(0 / 1)$ & $0.0(0 / 1)$ & $0.0(0 / 1)$ & \\
\hline P102L & $12.5(1 / 8)$ & $66.7(2 / 3)$ & $100(2 / 2)$ & $0.0(0 / 2)$ \\
\hline P105L & $0.0(0 / 1)$ & $0.0(0 / 1)$ & $0.0(0 / 1)$ & \\
\hline FFI & $13.0(3 / 23)$ & $7.1(1 / 14)$ & $20.0(2 / 10)$ & $0.0(0 / 12)$ \\
\hline \multicolumn{5}{|c|}{ Stratification by codon 129 genotype } \\
\hline \multicolumn{5}{|l|}{ E200K } \\
\hline MM & $78.1(25 / 32)$ & & & \\
\hline MV & $88.2(15 / 17)$ & & & \\
\hline VV & $0.0(0 / 0)$ & & & \\
\hline \multicolumn{5}{|l|}{ V210I } \\
\hline MM & $77.8(21 / 27)$ & $p=0.06$ & & \\
\hline MV & $100.0(13 / 13)$ & & & \\
\hline VV & $0.0(0 / 0)$ & & & \\
\hline \multicolumn{5}{|l|}{ Others } \\
\hline MM & $100.0(6 / 6)$ & & & \\
\hline MV & $80.0(4 / 5)$ & & & \\
\hline VV & $50.0(2 / 4)$ & & & \\
\hline
\end{tabular}

onset $(p=0.014)$ and the PRNP codon 129 genotype (VV vs. MV $p=0.043$ ). Sensitivity of 14-3-3 was higher in old patients compared to young ones $(25.0 \%$ in patients younger than 40 years, 83.9 in patients aged 40-60 years, $86.5 \%$ in $60-80$ years and $100 \%$ in patients older than 80 years).

Regarding the percentage of abnormal findings in the 14-3-3 test in relation to the PRNP codon 129 genotype, this was lower in gCJD patients homozygous for valine than in heterozygous patients (VV vs. MV $p=0.043$ ). However, when we adjusted by type of mutation, this statistical significance was lost. Although the 14-3-3 test performed worse in homozygous for methionine than in heterozygous gCJD patients, this difference was not significant ( $\chi^{2}$ test, $p=0.08$ ) (Table 3 ). In E200K and V210I patients, the 14-3-3 sensitivity was higher in heterozygous $(88.2$ and $100 \%)$ than in methionine homozygous patients
(78.1 and $77.8 \%$ ), but these differences did not reach any significance (Table 2).

Disease duration had no influence on 14-3-3 test results $(84.6 \%$ abnormal findings in patients with disease duration below the median, and $87.3 \%$ in patients with disease duration above the median survival time, Table 3). In gCJD patients, there was no significant influence of the disease stage at the time of lumbar puncture in relation to $14-3-3$ results $(p=0.4)(100 \%$ in te first third of disease duration, $89 \%$ in the second third and $82 \%$ in the last third, Table 3 , as reported in sporadic CJD [21].

Regarding the other CSF tests, there was a lower percentage of abnormal findings for the S100b test in gCJD patients homozygous for methionine than in heterozygous patients, while the opposite was found for tau and NSE (Table 3), though the differences were not statistically 
Table 3 Sensitivity of tests in gCJD

\begin{tabular}{|c|c|c|c|c|}
\hline Characteristics & $\begin{array}{l}\text { Number of } 14-3-3 \\
\text { positive patients/total }\end{array}$ & $\begin{array}{l}\text { Number of tau positive } \\
\text { patients/total }\end{array}$ & $\begin{array}{l}\text { Number of S100b positive } \\
\text { patients/total }\end{array}$ & $\begin{array}{l}\text { Number of NSE positive } \\
\text { patients/total }\end{array}$ \\
\hline \multicolumn{5}{|l|}{ Age at onset } \\
\hline$<40$ & $1 / 4$ & $1 / 1$ & $1 / 1$ & $1 / 1$ \\
\hline $40-60$ & $47 / 57$ & $18 / 19$ & $9 / 11$ & $11 / 15$ \\
\hline $60-80$ & $46 / 53$ & $18 / 21$ & $9 / 9$ & $6 / 11$ \\
\hline$>80$ & $2 / 2$ & $1 / 1$ & - & - \\
\hline$p$-value & 0.016 & 0.76 & 0.34 & 0.47 \\
\hline \multicolumn{5}{|l|}{ Codon 129} \\
\hline MM & $52 / 65$ & $22 / 22$ & $7 / 8$ & $9 / 12$ \\
\hline MV & $32 / 35$ & $11 / 14$ & $9 / 10$ & $6 / 12$ \\
\hline VV & $2 / 4$ & $2 / 2$ & $1 / 1$ & $2 / 2$ \\
\hline$p$ value & 0.075 & 0.06 & 0.93 & 0.25 \\
\hline \multicolumn{5}{|l|}{ Disease duration } \\
\hline$>$ median & $22 / 26$ & $10 / 11$ & $5 / 5$ & $7 / 9$ \\
\hline$<$ median & $48 / 55$ & $21 / 21$ & $9 / 10$ & $8 / 12$ \\
\hline$p$ value & 0.74 & 0.16 & 0.46 & 0.58 \\
\hline \multicolumn{5}{|c|}{ Time point of LP during disease ${ }^{a}$} \\
\hline Early stage & $8 / 8$ & $1 / 1$ & $1 / 1$ & $0 / 1$ \\
\hline Middle stage & $23 / 26$ & $7 / 7$ & $3 / 3$ & $3 / 3$ \\
\hline Advanced stage & $28 / 34$ & $7 / 7$ & $3 / 3$ & $2 / 2$ \\
\hline$p$ value & 0.40 & - & - & 0.17 \\
\hline
\end{tabular}

${ }^{a}$ For the estimation of the disease stage when the LP was performed we divided the individual disease duration in thirds and calculated the time of lumbar puncture according to the first third of the total duration of the disease (early stage), the second (middle) or the third (advanced stage) of the disease

significant $(p=0.06$ for tau, $p=0.92$ for $\mathrm{S} 100 \mathrm{~b}$, and $p=0.24$ for NSE, $\chi^{2}$ test).

Multivariate analysis, performed on all gTSE patients, included as variables disease duration, age at onset, gender, type of mutation and 129 genotype, and as covariates gender and country of residence. This analysis revealed that the type of mutation is the only variable that significantly influenced $14-3-3$ test $(p<0.004)$. Particularly, in patients carrying the D178N-Met mutation (FFI), the percentage of abnormal findings of 14-3-3 decreased significantly in comparison to gCJD $(p<0.007)$ and insert gTSE $(p<0.001)$. Interestingly, regarding the 129 codon polymorphism, 14-3-3 had lower percentage of abnormal tests in patients homozygous for valine than in patients homozygous for methionine or heterozygous, though no significant differences were found (crude $p$ value $=0.5$; adjusted $p$ value $=0.76$ ). Table 4 .

Multivariate analysis did not revealed any variables that influenced tau, NSE or S100b levels in gTSE patients.

In all gTSE there was a statistically significant negative correlation between tau levels and disease duration (Spearman $\rho 2$ between duration and tau levels $=-0.52$ $(p<0.001)$. However, when the data were stratified by diagnostic groups, numbers become too low and were not significant (only borderline for gCJD: $r^{2}=-0.32$, $p=0.057)$.

\section{Discussion}

Data on brain-derived proteins in the CSF of patients with genetic TSE are limited and conflicting results have been reported, mostly because they are frequently based on single case observations (see Table 4). In these reports, sensitivity of biochemical markers in CSF is reported to be lower than in sporadic CJD and this was explained in terms of prolonged disease duration and relatively slow disease progression. Because of the limited numbers of patients, no detailed analysis on this topic is available.

In this study we provide data on four brain-derived proteins in a cohort of patients with various forms of genetic TSE. We found firm evidence for elevated concentrations of 14-3-3, tau, S100b and NSE in the CSF of patients with genetic CJD, but not in FFI or GSS patients. Of interest, the median concentrations for tau, S100b and NSE were similar to those detected in sporadic CJD in other studies $[1,16,20]$. In our previous study on sporadic CJD, we reported median tau levels in the range of 
Table 4 CSF biomarker in genetic TSE (reports in the literature)

\begin{tabular}{|c|c|c|c|c|c|c|c|}
\hline Author & Journal & Mutation & $n$ & $14-3-3$ & tau & nse & S100b \\
\hline \multicolumn{8}{|l|}{ E200K } \\
\hline Rosenmann [18] & Neurology 1999 & E200K & 16 & $94 \%$ & & & \\
\hline Cataldi [4] & Neurol Sci 2000 & E200K & 1 & + & & & \\
\hline Kovacs [11] & Hum Gen 2005 & E200K & 62 & $89 \%$ & & & \\
\hline Sanchez-Valle [23] & Eur J Neurol 2004 & E200K & 5 & $100 \%$ & & & \\
\hline Ladogana [15] & Neurology 2005 & E200K V210I & 95 & $\begin{array}{l}81 \% \text { in } \mathrm{MM}, 95 \% \\
\text { in } \mathrm{MV}+\text { in VV }\end{array}$ & & & \\
\hline \multicolumn{8}{|l|}{ V210I } \\
\hline Kovacs [11] & Hum Gen 2005 & V210I & 35 & $100 \%$ & & & \\
\hline Huang [7] & Arq neuropsiquiatr 2001 & V210I & 1 & - & & & \\
\hline \multicolumn{8}{|l|}{ D178N } \\
\hline Zerr [30] & Neurology 1998 & D178N-129M & 8 & - & & & \\
\hline Sanchez-Valle [23] & Eur J Neurol 2004 & D178N-129M & 2 & $0 \%$ & & & \\
\hline Kovacs [11] & Hum Gen 2005 & D178N 129V & 22 & $10 \%$ & & & \\
\hline Rosenmann [18] & Neurology 1999 & D178N 129V & 1 & + & & & \\
\hline \multirow[t]{3}{*}{ Zarranz [29] } & JNNP 2005 & D178N & 4 & $0 \%$ & & & \\
\hline & & $129 \mathrm{MM}$ & 2 & $50 \%$ & & & \\
\hline & & $\mathrm{D} 178 \mathrm{~N}+\mathrm{MV}$ & & & & & \\
\hline Rosenmann [19] & Acta Neurol Scand 1998 & D178N-129V & 2 & + & & & \\
\hline \multicolumn{8}{|l|}{ P102L } \\
\hline Imaiso [8] & Rinsho Shinkeigaku 1998 & P102L & 1 & + & & Elevated & \\
\hline Kovacs [11] & Hum Gen 2005 & P102L & 7 & $57 \%$ & & & \\
\hline \multicolumn{8}{|l|}{ Others } \\
\hline Krebs [13] & Neurogenetics 2005 & R148H & 1 & + & & & \\
\hline Iwaski [9] & Rinsho Shinkeigaku. 1999 & V180I & 1 & Not done & & 30 & \\
\hline Collins [5] & Arch Neurol 2000 & T188A & 1 & + & & & \\
\hline Kotta [10] & BMC Infect dis 2006 & T193I & 1 & + & & & \\
\hline Tumani [25] & DMW 2002 & E196K & 1 & + & Elevated & Elevated & \\
\hline Capellari [3] & Neurology 2005 & R208H & 1 & + & & & \\
\hline Roeber [17] & Acta Neuropathol 2005 & R208H & 1 & + & & & \\
\hline Ladogana [14] & Am J Med Gen 2001 & E211Q & 1 & + & & & \\
\hline Sanchez-Vallez [22] & JNNP 2008 & 9OPRI & 1 & - & & & \\
\hline
\end{tabular}

$6,000 \mathrm{pg} / \mathrm{ml}$, which is not significantly different from what we found in gCJD patients [21]. These results are concordant with the observation that some gCJD might present clinical similarities with sporadic CJD [11, 15]. Indeed, these cases are often misclassified as sporadic CJD if family history and genetic testing are not done.

The rate of elevated levels of 14-3-3, tau, NSE and $\mathrm{S} 100 \mathrm{~b}$ in genetic CJD was comparable to that observed in sporadic CJD [3, 20, 26, 27]. In other forms of gTSE, such as FFI and GSS, these tests were consistently negative. Although levels of tau in FFI and GSS patients were lower than the cut-off levels given for CJD, they were still elevated if compared to non-demented controls [24].

The crude analyses of disease modifying factors of the 14-3-3 test in gCJD revealed that age at onset and PRNP codon 129 genotype influenced sensitivity. 14-3-3 test sensitivity was lower in patients with disease onset before 40 years. These data parallel the results performed on sporadic CJD [20]. However, while in the multivariate analysis age remained as an independent variable in sporadic CJD, in gCJD it did not. Interestingly, in gCJD the PRNP codon 129 genotype influences 14-3-3 sensitivity in a different way with respect to what has been observed in sporadic CJD. Valine homozygous gCJD patients had a lower sensitivity in the 14-3-3 test than heterozygous patients. Though there are too few patients to draw any definite conclusions, a possible explanation might be that the PRNP mutations coupled with the valine alleles (R208H, D178N, E196K) confer low sensitivity to 14-3-3.

The biological significance of brain-derived proteins in the CSF of patients with TSEs remains to be determined. It is generally assumed that the release of 14-3-3, tau and 
NSE proteins in the CSF is a consequence of leakage into the CSF following rapid neuronal damage. Recently, a systematic analysis of brain-derived proteins in CSF and neuropathological lesions has shown that the levels of these proteins are the consequence of both the degree of neuronal damage and the localization of the most affected areas [2]. For example NSE levels correlated with damage of subcortical areas (such as the thalamus) and tau protein levels correlated with the degree of spongiform changes in the frontal cortex. Our findings on inverse correlation of tau levels and the number of octapeptide repeats are of interest, since the number of repeats has been correlated to the type of cerebellar PrPSc deposits [28].

In conclusion, the validity of the biomarkers varied among the different forms of gTSEs. Sensitivity of biomarkers was high in those forms, which are clinically more similar to sporadic CJD, such as genetic CJD and insert gTSEs.

Acknowledgments We thank all physicians in the participating countries for sending us the cerebrospinal fluid and blood samples and for providing pertinent clinical and neuropathological data on those patients. We thank Dr. Gabor Kovacs for his help and advice. The collaborative study was funded by grants from the European Commission (EC) (QLG3-CT-2002-81606). The national studies were supported in Greece by the Greek Ministry of Health, through KEEL (Center for Control of Infectious Diseases), in Italy by the Ministry of Health and the Istituto Superiore di Sanità, in the Netherlands, in Slovakia by Ministry of Health and European Commission (SEECCJD project), in Spain a grant from the Ministerio de Ciencia y Tecnología (MCyT EET 2001/2216) and Spanish Ministerio de Sanidad y Consumo, grant number DGVI 1312/04-1, in Switzerland by Bundesamt für Gesundheit, Bern (NRPE-BAG contracts $\mathrm{n}^{\circ}$ 03.001297and $n^{\circ}$ 04.002363), in United Kingdom by the Department of Health and the Scottish Home Office Department of Health and in Germany by the Bundesministerium für Gesundheit und Soziale Sicherung (BMGS) (GZ: 325-4471-02/15) and by the Bundesministerium für Bildung und Forschung (BMBF) (KZ: 0312720 to I.Z).

Conflict of interest statement The authors report no conflicts of interest.

\section{References}

1. Bahl JM, Heegaard NH, Falkenhorst G, Laursen H, Hogenhaven H, Molbak K, Jespersgaard C, Hougs L, Waldemar G, Johannsen P, Christiansen M (2008) The diagnostic efficiency of biomarkers in sporadic Creutzfeldt-Jakob disease compared to Alzheimer's disease. Neurobiol Aging. doi:101016/j.neurobiolaging.2008.01.013

2. Boesenberg-Grosse C, Schulz-Schaeffer WJ, Bodemer M, Ciesielczyk B, Kretzschmar HA, Green AJ, Zerr I (2006) Brainderived proteins in the CSF, do they correlate with brain pathology in CJD? BMC Neurol 6:35. doi:10.1186/14712377-6-35

3. Capellari S, Cardone F, Notari S, Schininà ME, Maras B, Sità D, Baruzzi A, Pocchiari M, Parchi P (2005) Creutzfeldt-Jakob disease associated with the $\mathrm{R} 208 \mathrm{H}$ mutation in the prion protein gene. Neurology 64:905-907
4. Cataldi ML, Restivo O, Reggio E, Restivo DA, Reggio A (2000) Deafness: an unusual onset of genetic Creutzfeldt-Jakob disease. Neurol Sci 21:53-55. doi:10.1007/s100720070119

5. Collins S, Boyd A, Fletcher A, Byron K, Harper C, McLean CA, Masters CL (2000) Novel prion protein gene mutation in an octogenarian with Creutzfeldt-Jakob disease. Arch Neurol 57:1058-1063. doi:10.1001/archneur.57.7.1058

6. Cuadrado-Corrales N, Jiménez-Huete A, Albo C, Hortiguela R, Vega L, Cerrato L, Sierra-Moros M, Rábano A, de Pedro-Cuesta J, Calero M (2006) Impact of the clinical context on the 14-3-3 test for the diagnosis of sporadic CJD. BMC Neurol 6:25. doi: 10.1186/1471-2377-6-25

7. Huang N, Marie SK, Kok F, Nitrini R (2001) Familial Creutzfeldt-Jakob disease associated with a point mutation at codon 210 of the prion protein gene. Arq Neuropsiquiatr 59:932-935. doi: 10.1590/S0004-282X2001000600017

8. Imaiso Y, Mitsuo K (1998) Gerstmann-Sträussler-Scheinker syndrome with a Pro102Leu mutation in the prion protein gene and atypical MRI findings, hyperthermia, tachycardia, and hyperhidrosis. Rinsho Shinkeigaku 38:920-925

9. Iwaski $\mathrm{Y}$, Sone $\mathrm{M}$, Kato $\mathrm{T}$, Yoshida $\mathrm{E}$, Indo $\mathrm{T}$, Yoshida $\mathrm{M}$, Hashizume Y, Yamada M (1999) Clinicopathological characteristics of Creutzfeldt-Jakob disease with a PrP V180I mutation and M129V polymorphism on different alleles. Rinsho Shinkeigaku 39:800-806

10. Kotta K, Paspaltsis I, Bostantjopoulou S, Latsoudis H, Plaitakis A, Kazis D, Collinge J, Sklaviadis T (2006) Novel mutation of the PRNP gene of a clinical CJD case. BMC Infect Dis 6:169. doi:10.1186/1471-2334-6-169

11. Kovacs GG, Puopolo M, Ladogana A, Pocchiari M, Budka H, Van Duijn C, Collins S, Boyd A, Guilivi A, Coulthart M, Delasnerie-Laupretre N, Brandel JP, Zerr I, Kretzschmar H, de Pedro-Cuesta J, Calero-Lara M, Glatzel M, Aguzzi A, Bishop M, Knight R, Belay G, Will R, Mitrova E (2005) Genetic prion disease: the EUROCJD experience. Hum Genet 118:166-174. doi:10.1007/s00439-005-0020-1

12. Kovács GG, Trabattoni G, Hainfellner JA, Ironside JW, Knight RS, Budka H (2002) Mutations of the prion protein gene. Phenotypic spectrum. J Neurol 249:1567-1582. doi:10.1007/s00415002-0896-9

13. Krebs B, Lederer R-M, Windl O, Grasbon-Frodl E-M, Zerr I, Kretzschmar HA (2005) Creutzfeldt-Jakob disease associated with an R148H mutation of the prion protein gene. Neurogenetics 6:97-100. doi:10.1007/s10048-004-0208-x

14. Ladogana A, Almonti S, Petraroli R, Giaccaglini E, Ciarmatori C, Liu QG, Bevivino S, Squitieri F, Pocchiari M (2001) Mutation of the PRNP gene at codon 211 in familial Creutzfeldt-Jakob disease. Am J Med Genet 103:133-137. doi:10.1002/ajmg.1511

15. Ladogana A, Puopolo M, Poleggi A, Almonti S, Mellina V, Equestre M, Pocchiari M (2005) High incidence of genetic human transmissible spongiform encephalopathies in Italy. Neurology 64:1592-1597. doi:10.1212/01.WNL.0000160118.26865.11

16. Otto M, Wiltfang J, Cepek L, Neumann M, Mollenhauer B, Steinacker P, Ciesielczyk B, Schulz-Schaeffer W, Kretzschmar HA, Poser S (2002) Tau protein and 14-3-3 protein in the differential diagnosis of Creutzfeldt-Jakob disease. Neurology 58:192-197

17. Roeber S, Krebs B, Neumann M, Windl O, Zerr I, Grasbon-Frodl EM, Kretzschmar HA (2005) Creutzfeldt-Jakob disease in a patient with an R208H mutation of the prion protein gene (PRNP) and a 17-kDa prion protein fragment. Acta Neuropathol 109:443448. doi:10.1007/s00401-004-0978-0

18. Rosenmann H, Kahana E, Korczyn AD, Kahana I, Chapman J, Gabizon R (1999) Preliminary evidence for anticipation in genetic E200K Creutzfeldt-Jakob disease. Neurology 53:13281329 
19. Rosenmann H, Vardi J, Finkelstein Y, Chapman J, Gabizon R (1998) Identification in Israel of 2 Jewish Creutzfeldt-Jakob disease patients with a 178 mutation at their PrP gene. Acta Neurol Scand 97:184-187

20. Sanchez-Juan P, Green A, Ladogana A, Cuadrado-Corrales N, Sanchez-Valle R, Mitrova E, Stoeck K, Sklaviadis T, Kulczycki J, Hess K, Bodemer M, Slivarichova D, Saiz A, Calero M, Ingrosso L, Knight R, Janssens C, Van Duijn C, Zerr I (2006) CSF tests in the differential diagnosis of Creutzfeldt-Jakob disease. Neurology 67:637-643. doi:10.1212/01.wnl.0000230159. 67128.00

21. Sanchez-Juan P, Sanchez-Valle R, Green A, Ladogana A, Cuadrado-Corrales N, Mitrova E, Stoeck K, Sklaviadis T, Kulczycki J, Hess K, Krasnianski A, Equestre M, Slivarichova D, Saiz A, Calero M, Pocchiari M, Knight R, van Dujin CM, Zerr I (2007) Influence of timing on CSF tests value for CreutzfeldtJakob disease diagnosis. J Neurol 254:901-906. doi:10.1007/ s00415-006-0472-9

22. Sanchez-Valle R, Aróstegui JI, Jague J, Rami R, Lladó A, Molinuevo JL (2008) First demonstrated de novo insertion in the prion protein gene in a young patient with dementia. J Neurol Neurosurg Psychiatry 79(7):845-846

23. Sanchez-Valle R, Nos C, Yague J, Graus F, Dominguez A, Saiz A (2004) Clinical and genetic features of human prion diseases in Catalonia: 1993-2002. Eur J Neurol 11:649-655. doi:10.1111/ j.1468-1331.2004.00967.x

24. Sunderland T, Linker G, Mirza N, Putnam KT, Friedman DL, Kimmel LH, Bergeson J, Manetti GJ, Zimmermann M, Tang B, Bartko JJ, Cohen RM (2003) Decreased B-amyloid 1-42 and increased tau levels in cerebrospinal fluid of patients with Alzheimer disease. JAMA 289:2094-2103. doi:10.1001/jama.289. 16.2094

25. Tumani H, Windl O, Kretzschmar HA, Ludolph AC (2002) Clinically atypical CJD: diagnostic relevance of cerebrospinal fluid markers and molecular genetic analysis? Dtsch Med Wochenschr 127:318-320. doi:10.1055/s-2002-20148

26. Van Everbroeck B, Boons J, Cras P (2005) Cerebrospinal fluid biomarkers in Creutzfeldt-Jakob disease. Clin Neurol Neurosurg 107:355-360. doi:10.1016/j.clineuro.2004.12.002

27. Van Everbroeck B, Quoilin S, Boons J, Martin JJ, Cras P (2003) A prospective study of CSF markers in 250 patients with possible Creutzfeldt-Jakob disease. J Neurol Neurosurg Psychiatry 74:1210-1214. doi:10.1136/jnnp.74.9.1210

28. Vital C, Gray F, Vital A, Parchi P, Capellari S, Petersen RB, Ferrer X, Jarnier D, Julien J, Gambetti P (1998) Prion encephalopathy with insertion of octapeptide repeats: the number of repeats determines the type of cerebellar deposits. Neuropathol Appl Neurobiol 24:125-130. doi:10.1046/j.1365-2990.1998. 00098.x

29. Zarranz JJ, Digon A, Atares B, Rodriguez-Martinez AB, Arce A, Carrera N, Fernandez-Manchola I, Fernandez-Martinez M, Fernandez-Maiztegui C, Forcadas I, Galdos L, Gomez-Esteban JC, Ibanez A, Lezcano E, Lopez de Munain A, Marti-Masso JF, Mendibe MM, Urtasun M, Uterga JM, Saracibar N, Velasco F, de Pancorbo MM (2005) Phenotypic variability in familial prion diseases due to the D178N mutation. J Neurol Neurosurg Psychiatry 76:1491-1496. doi:10.1136/jnnp.2004.056606

30. Zerr I, Giese A, Windl O, Kropp S, Schulz-Schaeffer W, Riedemann C, Skworc K, Bodemer M, Kretzschmar HA, Poser S (1998) Phenotypic variability in fatal familial insomnia (D178N129M) genotype. Neurology 51:1398-1405

31. Zerr I, Pocchiari M, Collins S, Brandel JP, de Pedro Cuesta J, Knight RSG, Bernheimer H, Cardone F, Delasnerie-Lauprêtre N, Cuadrado Corrales N, Ladogana A, Fletcher A, Bodemer M, Awan T, Ruiz Bremón A, Budka H, Laplanche JL, Will RG, Poser S (2000) Analysis of EEG and CSF 14-3-3 proteins as aids to the diagnosis of Creutzfeldt-Jakob disease. Neurology 55:811815 